\title{
THE EFFECT OF COMPOST AND SEWAGE SLUDGE ON SOIL BIOLOGIC ACTIVITIES IN SALT AFFECTED SOIL
}

\author{
Abdelbasset Lakhdar ${ }^{1,3}$, Rosalia Scelza ${ }^{2}$, Riccardo Scotti ${ }^{2}$, Maria A. Rao ${ }^{2 *}$, Naceur \\ Jedidi $^{3}$, Liliana Gianfreda ${ }^{2}$, Chedly Abdelly ${ }^{1}$ \\ ${ }^{1}$ Laboratoire d'Adaptation des Plantes aux Stress Abiotiques, Centre de Biotechnologies, \\ Technopole Borj Cedria, BP 901, Hammam Lif 2050, Tunisia. ${ }^{2}$ Dipartimento di Scienze del \\ Suolo, della Pianta, dell'Ambiente e delle Produzioni Animali, Università di Napoli Federico II, \\ Portici, Italy. ${ }^{3}$ Centre de Recherches et Technologies des Eaux, Technopole Borj Cedria, BP 273, \\ Soliman 8020, Tunisia. *Corresponding author: mariarao@unina.it
}

\begin{abstract}
Saline soil was amended with 13.3 and $26.6 \mathrm{~g} \mathrm{~kg}^{-1}$ of Municipal Solid Waste (MSW) compost or sewage sludge, and arylsulphatase (ARY), phosphatase (PHO), dehydrogenase (DEH), $\beta$-glucosidase ( $\beta$-GLU), urease (URE) and catalase (CAT) activities as well as physical-chemical properties were determined after 70 day of incubation under laboratory conditions. MSW compost and sewage sludge significantly improved soil physical-chemical properties, especially carbon and nitrogen contents. Accordingly, overall enzyme activities were substantially promoted in presence of both amendments and the higher increases were measured at $13.3 \mathrm{~g} \mathrm{~kg}^{-1}$ of MSW compost (increases by $107 \%, 43 \%, 20 \%, 11 \%$, and $148 \%$ for, DEH, $\beta$-GLU, PHO, URE, and CAT, respectively). Lower beneficial effects occurred at $26.6 \mathrm{~g} \mathrm{~kg}^{-1}$ of sewage sludge possibly because of the increased salinity or the presence of trace elements by sewage sludge application. As a general response, MSW compost supplied at $13.3 \mathrm{~g} \mathrm{~kg}^{-1}$ seems to be a useful strategy to enhance biologic activities of salt-affected soil.
\end{abstract}

Keywords: Biologic activities, MSW compost, saline soil, sewage sludge.

\section{INTRODUCTION}

Salt toxicity is one of the major edaphic factors limiting crop production and ecoenvironmental quality in salt-affected soils throughout the world (Hanay et al., 2004; Liang et al., 2005). Excessive amounts of salts have adverse effect on physical and chemical properties and on biologically mediated processes in the soil, such as $\mathrm{C}$ and $\mathrm{N}$-mineralization (Tejada et al., 2006). Sal toxicity may also constitute an important abiotic concern affecting plant yield in arid and semiarid regions (Lakhdar et al., 2008).

Various organic amendments such as Municipal Solid Waste (MSW) compost or Sewage sludge have been investigated for their effectiveness in saline soil remediation (Tejada et al., 2006; Walker and Bernal, 2008). The application of organic matter to saline soils can have 
different effects such as speeding up of $\mathrm{NaCl}$ leaching, decrease of the exchangeable sodium percentage and electrical conductivity and increase of water infiltration (El-Shakweer et al., 1998). Meanwhile, the application of biosolids increases soil microbial biomass and some soil enzymatic activities such as urease, alkaline phosphatase and $\beta$ glucosidase linked to $\mathrm{C}, \mathrm{N}, \mathrm{P}$ and $\mathrm{S}$ soil cycles (Liang et al., 2003; Tejada et al. 2006). In fact hydrolytic enzymes are sensitive indicators of management induced changes in soil properties due to their strong relationship with soil organic matter content and quality (Masciandaro et al., 2004).

According to Rao and Pathak (1996) and Liang et al. (2005), the incorporation of organic amendments to soil stimulate dehydrogenase activity because the added material may contain intra- and extracellular enzymes and may also stimulate microbial activity in the soil. These parameters are the most sensitive to the changes which occur in salt-affected soil, and provide rapid and accurate information on changes in soil quality.

A simulated salinized experiment was performed in this study to examine the effects of MSW compost and sewage sludge incorporated in salt affected soil on the activity of some key enzymes related to nutrient cycling (arylsulphatase, phosphatase, deydrogenase, $\quad \beta$ glucosidase, urease and catalase).

\section{MATERIALS AND METHODS}

\section{Experimental design}

A loam-silt, saline soil was collected from salt-affected ecosystem Sebkha Soliman (North-East Tunisia), dried and sieved at
$2 \mathrm{~mm}$. The main soil properties were: $23 \%$ clay, $55 \%$ silt, $22 \%$ sand, and $\mathrm{pH}$ (1:25) 8.2, total $\mathrm{CaCO}_{3} 23 \%$, EC 75 dS $\mathrm{m}^{-1}$.

Municipal solid waste (MSW) compost was collected from composting station of Beja (North Tunisia). It was mechanically produced by mixing weekly the waste heap under aerobic conditions by fast fermentation and aged 8 months before use. Urban secondary sewage sludge was obtained from the activated sludge waste water treatment plant of Radès near Tunis, Tunisia. The aerobic digested sludge was previously air dried. Table 1 shows the main chemical properties of MSW compost and S sludge In a completely randomized experimental design with three replications, Hordeum maritimum seeds were sown in pots containing $1 \mathrm{~kg}$ of soil in a growth chamber with $14 / 10 \mathrm{~h}$ light/dark cycle, $22 / 18^{\circ} \mathrm{C}$ day/night temperature, Photosynthetic Active Radiations (PAR) of $200 \mathrm{mmol} \mathrm{m}^{-2} \mathrm{~s}^{-1} \mathrm{PAR}$, and a relative humidity of $60-80 \%$.

The soil was previously amended with two amounts of MSW compost ( $\mathrm{C} 1$ and $\mathrm{C} 2$ ) or sewage sludge (S1 and S2), 13.3 and $26.6 \mathrm{~g} \mathrm{~kg}^{-1} \quad$ corresponding respectively to 40 and $80 \mathrm{t} \mathrm{ha}^{-1}$ soil. A non-amended soil served as control soil. After 70 days incubation, moistened soil samples were collected for enzymatic assays. Plant responses were previously studied by Lakhdar et al. (2008).

\section{Enzymatic activity assays}

Enzyme activities were determined on fresh, moist, sieved $(<2 \mathrm{~mm})$ soils. Substrates, i.e., p-nitrophenyl- $\beta$-Dglucoside and $p$-nitrophenyl-phosphate, for $\beta$-glucosidase $(\beta$-GLU) (E.C. 3.2.1.21) and phosphatase (PHO) (E.C. 3.1.3.2) were used, respectively. 
Table 1. MSW compost and sewage sludge characteristics (means and standards calculated on three replication basis).

\begin{tabular}{lcc}
\hline & MSW compost & Sewage sludge \\
\hline $\mathrm{pH}$ & $7.90 \pm 0.04$ & $7.07 \pm 0.50$ \\
$\mathrm{EC}\left(\mu \mathrm{S} \mathrm{cm}^{-1}\right)$ & $8 \cdot 10^{3} \pm 40$ & $1.01 \cdot 10^{3} \pm 50$ \\
$\mathrm{C}\left(\mathrm{g} \mathrm{kg}^{-1}\right)$ & $130 \pm 22$ & $272 \pm 20$ \\
$\mathrm{~N}\left(\mathrm{~g} \mathrm{~kg}^{-1}\right)$ & $11.4 \pm 0.6$ & $38.7 \pm 8.0$ \\
$\mathrm{C} / \mathrm{N}$ & $11.4 \pm 1.8$ & $7.0 \pm 0.8$ \\
$\mathrm{P}_{2} \mathrm{O}_{5}\left(\mathrm{~g} \mathrm{~kg}^{-1}\right)$ & $0.24 \pm 0.01$ & $0.10 \pm 0.01$ \\
$\mathrm{~K}^{+}\left(\mathrm{g} \mathrm{kg}^{-1}\right)$ & $1.80 \pm 0.09$ & $0.85 \pm 0.05$ \\
$\mathrm{Cu}^{2+}\left(\mathrm{mg} \mathrm{kg}^{-1}\right)$ & $91.6 \pm 13.2$ & $284.0 \pm 2.3$ \\
$\mathrm{~Pb}^{2+}\left(\mathrm{mg} \mathrm{kg}^{-1}\right)$ & $251.6 \pm 12.1$ & $101.7 \pm 2.9$ \\
$\mathrm{Zn}^{2+}\left(\mathrm{mg} \mathrm{kg}^{-1}\right)$ & $290.2 \pm 11.1$ & $592.7 \pm 21.7$ \\
\hline
\end{tabular}

Briefly, $1 \mathrm{~g}$ of soil was incubated with 5 $\mathrm{ml}$ of buffered substrate in reaction flasks for $1 \mathrm{~h}$ at $30^{\circ} \mathrm{C}$, under continuous stirring. Specific buffers and pHs were used as reported in Sannino and Gianfreda (2001) and Eivazi and Tabatabai (1990). Enzymatic reactions were stopped by rapidly transferring the mixtures to a freezer and holding them there for $10 \mathrm{~min}$. Concentrations of $p$-nitrophenol were determined at $400 \mathrm{~nm}$ after addition of $\mathrm{NaOH}$ and $\mathrm{CaCl}_{2}$ for $\mathrm{PHO}$ and Tris/NaOH buffer ( $\mathrm{pH} 10.0)$ and $\mathrm{CaCl}_{2}$ for $\beta$-GLU.

The activity of urease (URE) (E.C. 3.5.1.5) and arylsulphatase (ARY, E.C. 3.1.6.1) were determined as described by Kandeler and Gerber (1988) and Tabatabai and Bremner (1970), respectively. Dehydrogenase (DEH) (E.C. 1.1. Activity was measured by mixing $1 \mathrm{~g}$ of soil with $1 \mathrm{ml}$ of buffered tetrazolium salts (TTC) solution, according to Trevors (1984). Catalase (CAT, E.C. 1.11.1.6) activity was determined according to RodriguezKabana and Truelove, 1982.

One unit of enzyme activity was defined as the number of $\mu$ moles (for $\beta$ GLU) or $\mu$ grams (for DEH, FDAH, NR and URE) of product released at $30^{\circ} \mathrm{C} \mathrm{h}^{-1}$ by $1 \mathrm{~g}$ of dried soil. Control tests with autoclaved soils were carried out to evaluate the spontaneous or abiotic transformation of substrates.

All determinations were made in triplicate and data were corrected to ovendry $\left(105^{\circ} \mathrm{C}\right)$ moisture content.

\section{Statistical analysis}

Statistical analysis was performed by Analysis of variance (ANOVA) and Duncan's multiple range test was used to 
evaluate significant differences between means at $P \leq 0.05$. All statistical analyses were carried out with the program SPPS 13.0.

\section{RESULTS}

\section{Soil physical and chemical characteristics}

The addition of two doses of MSW compost and Sewage sludge had different effects on some of physico-chemical properties of the soil. They generally increased the values of all measured properties, as respect to the control soil. Different patterns were, however, observed according to the dose and type of used amendment (Table 2).
Different patterns were, however, observed according to the dose and type of used amendment (Table 2). For instance, no significant change of $\mathrm{pH}$ was observed under MSW compost, while a slight decrease was recorded with sewage sludge treatment. Both amendments induced an increase of EC especially at $26.6 \mathrm{~g} \mathrm{~kg}^{-1}$. EC increased by $30 \%$ and $33 \%$ in $\mathrm{C} 2$ and $\mathrm{S} 2$, respectively, while only $13-14 \%$ was detected at $13.3 \mathrm{~g} \mathrm{~kg}^{-1}$.

Increases were also measured for $\mathrm{C}$ and $\mathrm{N}$ contents. Indeed, carbon content increased up to 4.0-4.4-fold the value of control soil in $\mathrm{C} 1$ and $\mathrm{S} 1$, respectively, and much more (5.0-5.5 fold) in the presence of $26.6 \mathrm{~g} \mathrm{~kg}^{-1}$ of MSW compost and sewage sludge. A more moderate increase was measured for $\mathrm{N}$ that was on average $50 \%$ higher than that measured in

Table 2. Soil physical and chemical characteristics after the culture. Control: soil without amendment. $\mathrm{C} 1$ : soil amended with $13.3 \mathrm{~g} \mathrm{~kg}^{-1}$ of MSW compost; $\mathrm{C} 2$ : soil amended with $26.6 \mathrm{~g} \mathrm{~kg}^{-1}$ of MSW compost; $\mathrm{S} 1$ : soil amended with $13.3 \mathrm{~g} \mathrm{~kg}^{-1}$ of sewage sludge; S2: soil amended with $26.6 \mathrm{~g} \mathrm{~kg}^{-1}$ of sewage sludge. Data are the means of 3 replicates. Means followed by the same letters are not significantly different according to the Duncan's Multiple Range Test at $P \leq 0.05$.

\begin{tabular}{lccccc}
\hline & Control & $\mathrm{C} 1$ & $\mathrm{C} 2$ & $\mathrm{~S} 1$ & $\mathrm{~S} 2$ \\
\hline $\mathrm{pH}$ & $8.27 \pm 0.01 \mathrm{ab}$ & $8.28 \pm 0.04 \mathrm{ab}$ & $8.31 \pm 0.01 \mathrm{a}$ & $8.26 \pm 0.01 \mathrm{~b}$ & $8.22 \pm 0.01 \mathrm{c}$ \\
$\mathrm{EC}\left(\mu \mathrm{S} \mathrm{cm}^{-1}\right)$ & $647 \pm 29 \mathrm{c}$ & $741 \pm 10 \mathrm{~b}$ & $843 \pm 60 \mathrm{a}$ & $731 \pm 61 \mathrm{~b}$ & $863 \pm 100 \mathrm{a}$ \\
$\mathrm{C}\left(\mathrm{g} \mathrm{kg}^{-1}\right)$ & $2.5 \pm 0.1 \mathrm{c}$ & $10.9 \pm 0.2 \mathrm{~b}$ & $12.7 \pm 0.1 \mathrm{a}$ & $10.1 \pm 0.1 \mathrm{~b}$ & $13.7 \pm 0.3 \mathrm{a}$ \\
$\mathrm{N}\left(\mathrm{g} \mathrm{kg}^{-1}\right)$ & $1.2 \pm 0.1 \mathrm{c}$ & $1.8 \pm 0.1 \mathrm{~b}$ & $1.9 \pm 0.3 \mathrm{a}$ & $1.8 \pm 0.1 \mathrm{~b}$ & $2.1 \pm 0.1 \mathrm{a}$ \\
$\mathrm{C} / \mathrm{N}$ & $2.1 \pm 0.1 \mathrm{c}$ & $6.1 \pm 0.3 \mathrm{ab}$ & $6.7 \pm 0.3 \mathrm{a}$ & $5.6 \pm 0.1 \mathrm{~b}$ & $6.5 \pm 0.2 \mathrm{a}$ \\
$\mathrm{K}^{+}\left(\mathrm{mg} \mathrm{g}^{-1}\right)$ & $0.25 \pm 0.005 \mathrm{~b}$ & $0.27 \pm 0.004 \mathrm{a}$ & $0.24 \pm 0.01 \mathrm{~b}$ & $0.23 \pm 0.004 \mathrm{c}$ & $0.26 \pm 0.003 \mathrm{a}$ \\
$\mathrm{Ca}^{2+}\left(\mathrm{mg} \mathrm{g}^{-1}\right)$ & $0.16 \pm 0.01 \mathrm{~d}$ & $0.17 \pm 0.01 \mathrm{c}$ & $0.17 \pm 0.01 \mathrm{c}$ & $0.22 \pm 0.005 \mathrm{~b}$ & $0.34 \pm 0.01 \mathrm{a}$ \\
$\mathrm{Cu}^{2+}\left(\mathrm{mg} \mathrm{kg}^{-1}\right)$ & $15.65 \pm 0.35 \mathrm{~d}$ & $17.30 \pm 0.14 \mathrm{c}$ & $19.05 \pm 0.35 \mathrm{~b}$ & $18.75 \pm 0.3 \mathrm{~b}$ & $22.40 \pm 0.28 \mathrm{a}$ \\
$\mathrm{Pb}^{2+}\left(\mathrm{mg} \mathrm{kg}^{-1}\right)$ & $96.8 \pm 1.6 \mathrm{~b}$ & $103.6 \pm 6.4 \mathrm{~b}$ & $113.1 \pm 13.5 \mathrm{a}$ & $114.7 \pm 8.9 \mathrm{a}$ & $114.0 \pm 5.0 \mathrm{a}$ \\
$\mathrm{Zn}^{2+}\left(\mathrm{mg} \mathrm{kg}^{-1}\right)$ & $83.9 \pm 7.1 \mathrm{~d}$ & $86.6 \pm 8.0 \mathrm{c}$ & $89.9 \pm 14.0 \mathrm{~b}$ & $86.9 \pm 3 \mathrm{c}$ & $95.6 \pm 9.9 \mathrm{a}$ \\
\hline
\end{tabular}


the control soil in $\mathrm{C} 1, \mathrm{C} 2$ and $\mathrm{S} 1$ and only with the highest amount of sewage sludge reached a 1.75-fold increase.

Moderate increases or no statistically variations occurred for soil $\mathrm{K}^{+}$at both applied doses of either MSW compost or sewage sludge. The addition of the lower amount of MSW compost slightly raised $\mathrm{Ca}^{2+}$ value and no additional increase was monitored by doubling its quantity.

On the contrary, sewage sludge elevated the level of the cation from $0.16 \pm 0.01 \mathrm{mg} \mathrm{g}^{-1}$ of the control soil up to $0.22 \pm 0.005 \mathrm{mg} \mathrm{g}^{-1}$ and $0.34 \pm 0.01 \mathrm{mg} \mathrm{g}^{-1}$ at $13.3 \mathrm{~g} \mathrm{~kg}^{-1}$ and $26.6 \mathrm{~g} \mathrm{~kg}^{-1}$, respectively.

Heavy metal concentration at some extent increased or did not change in concomitance with MSW compost and sewage sludge supply. However with the higher dose of sewage sludge an increase by $50 \%$ of $\mathrm{Cu}^{2+}$ and by $14 \%$ of $\mathrm{Zn}^{2+}$ occurred as respect to their respective controls (Table 2).

\section{Enzymatic activities}

According to the substantial increase of $\mathrm{C}$ amount (and in turn of soil organic matter content), the levels of measured enzyme activities were generally enhanced by the application of the two amendments as respect to the non-amended soil (Table 3 ).

The highest pronounced increase was measured for DEH (by 107\%) and CAT

Table 3. Soil arylsluphatase (ARY, $\mu \mathrm{mol} p-\mathrm{NP} \mathrm{g}^{-1} \mathrm{~h}^{-1}$ ), phosphatase (PHO, $\mu$ mol $p$-NP $\mathrm{g}^{-1} \mathrm{~h}^{-1}$ ), dehydrogenase (DEH, $\mu \mathrm{g}$ TPF $\left.\mathrm{g}^{-1} \mathrm{~h}^{-1}\right), \beta$-glucosidase $\left(\beta\right.$-GLU, $\mu$ mol p-NP $\mathrm{g}^{-1}$ $\mathrm{h}^{-1}$ ), urease (URE, mg urea $\mathrm{g}^{-1} \mathrm{~h}^{-1}$ ) and catalase (CAT, $\mu \mathrm{mol} \mathrm{O} \mathrm{g}^{-1} \mathrm{~min}^{-1}$ ) activities after 70 days incubation. Control: soil without amendment. C1: soil amended with $13.3 \mathrm{~g} \mathrm{~kg}^{-1}$ of MSW compost; $\mathrm{C} 2$ : soil amended with $26.6 \mathrm{~g} \mathrm{~kg}^{-1}$ of MSW compost; S1: soil amended with $13.3 \mathrm{~g} \mathrm{~kg}^{-1}$ of sewage sludge; S2: soil amended with $26.6 \mathrm{~g} \mathrm{~kg}^{-1}$ of sewage sludge. Data are the means of 3 replicates. Means followed by the same letters are not significantly different according to the Duncan's Multiple Range Test at $P \leq$ 0.05 .

\begin{tabular}{lccccc}
\hline & Control & $\mathrm{C} 1$ & $\mathrm{C} 2$ & $\mathrm{~S} 1$ & $\mathrm{~S} 2$ \\
\hline DEH & $2.355 \pm 0.201 \mathrm{~d}$ & $4.875 \pm 0.653 \mathrm{a}$ & $3.053 \pm 0.541 \mathrm{c}$ & $2.885 \pm 0.153 \mathrm{c}$ & $3.257 \pm 0.161 \mathrm{~b}$ \\
$\beta$-GLU & $0.917 \pm 0.012 \mathrm{c}$ & $1.309 \pm 0.011 \mathrm{a}$ & $0.963 \pm 0.082 \mathrm{c}$ & $0.997 \pm 0.051 \mathrm{bc}$ & $1.063 \pm 0.042 \mathrm{~b}$ \\
PHO & $6.108 \pm 0.151 \mathrm{c}$ & $7.353 \pm 0.122 \mathrm{~b}$ & $6.020 \pm 0.234 \mathrm{c}$ & $7.787 \pm 0.270 \mathrm{a}$ & $5.901 \pm 0.234 \mathrm{c}$ \\
ARY & $0.257 \pm 0.014 \mathrm{e}$ & $0.278 \pm 0.013 \mathrm{~d}$ & $0.304 \pm 0.015 \mathrm{c}$ & $0.420 \pm 0.013 \mathrm{~b}$ & $0.538 \pm 0.021 \mathrm{a}$ \\
URE & $3.814 \pm 0.193 \mathrm{~b}$ & $4.237 \pm 0.101 \mathrm{a}$ & $3.806 \pm 0.164 \mathrm{~b}$ & $2.697 \pm 0.201 \mathrm{c}$ & $2.451 \pm 0.192 \mathrm{~d}$ \\
CAT & $2.111 \pm 0.521 \mathrm{~d}$ & $5.240 \pm 0.453 \mathrm{a}$ & $4.674 \pm 0.171 \mathrm{~b}$ & $3.506 \pm 0.173 \mathrm{c}$ & $3.503 \pm 0.504 \mathrm{c}$ \\
\hline
\end{tabular}

(by $148 \%$ ) activities in the presence of the lower MSW compost dose. Minor rises were detected for both enzymes at a double MSW quantity.
Sewage sludge also increased DEH and CAT activities but at a less extent as respect to compost and no variation was observed between the two applied doses. 
Among the four hydrolases, soil urease was the most affected by amendment and contrasting responses occurred with compost and sludge. As respect to the urease value of control soil, sludge decreases URE activity and much more at the higher applied dose (Table 3). By contrast, a 1.1-fold increment or no change was measured for URE activity in $\mathrm{C} 1$ and $\mathrm{C} 2$, respectively.

Significantly detectable increases also occurred for ARY activity in the presence of sewage sludge, whereas moderate effects were observed with compost (Table 3). Enhancements by $20 \%$ and $27 \%$ were monitored for $\mathrm{PHO}$ in $\mathrm{C} 1$ and $\mathrm{S} 1$, while no variation was observed in $\mathrm{C} 2$ and $\mathrm{S} 2$.

\section{DISCUSSION}

The low productivity of saline soils may be ascribed not only to their salt toxicity or damage caused by excess amounts of soluble salts but also to their low soil fertility (Liang et al., 2003). As expected, the added organic amendment (MSW compost and Sewage sludge) improved properties of salt-affected soil (Table 2).

No variation of soil $\mathrm{pH}$ was observed under $\mathrm{C} 1$ and $\mathrm{C} 2$, likely because MSW compost has a $\mathrm{pH}$ similar to that of the soil. On the contrary and in accordance with the findings of Tsadilas and Samaras (1998), Sewage sludge reduced slightly soil $\mathrm{pH}$ probably because its $\mathrm{pH}$ is close to neutrality. EC was similarly increased at two doses of both amendments.

Hargreaves et al. (2008) explained this fact by the presence of supra-optimal salt concentrations in both amendments. In addition, the application of organic matter promotes flocculation of clay minerals, which is an essential condition for the aggregation of soil particles allowing the increase of oxygen diffusion rate for soil micro-organisms. In addition enrichment of the rhizosphere with $\mathrm{Ca}^{2+}$ mainly observed in S2 treatment (Table 2), tends to replace exchangeable $\mathrm{Na}^{+}$on the adsorption sites accelerating saline water leaching (Garcia et al., 2000; Tejada et al., 2006).

In consistence with the findings of Madejon et al. (2001) and Marschner et al. (2003) both amendments improved soil $\mathrm{C}$ and $\mathrm{N}$ contents (Table 2).

Meanwhile, enzymatic activities were significantly stimulated (Table 3 ). This could possibly be related to a shift in microbial community towards the dominance of salt tolerable microorganisms (Li et al., 2006).

Oxidative enzymes, especially DEH, were proposed as a measure of overall microbial activity. DEH being an intracellular enzyme related to oxidative phosphorylation processes that occurs in all intact, viable microbial cells (Tejada et al., 2006).

Incorporation of both MSW compost and Sewage sludge stimulated DEH activity because the added material may contain intra- and extracellular enzymes and may also stimulate microbial activity in the soil (Liang et al., 2005). DEH was markedly increased at $\mathrm{C} 1$ treatment (Table 3). Accordingly, $\beta$-GLU, URE, PHO and CAT mostly increased in $\mathrm{C} 1$, thus supporting a general increment of the soil enzymatic activities upon compost addition. Pathak and Rao (1998), found a steady evolution of $\mathrm{CO}_{2}$ throughout 3 months of high salinity treatment showing a high activity of the heterotrophic microflora. However, C2 and S2 treatments seem to be supra-optimal doses, likely due to salinity or heavy metal increment. In fact, some studies indicated that high doses of some organic materials can introduce into the soil toxic compounds such as heavy metals which could have a negative effect on enzyme activities (Garcia et al., 1994). 
The only exception was soil ARY that was enhanced at high dose of both organic amendments.

The demand for $\mathrm{P}$ by soil microorganisms and plants may be responsible for the stimulation in the synthesis of this enzyme (Tejada et al., 2006). In addition, added organic matter (high increase of $\mathrm{C}$ content) likely may alleviate the 'salting-out' process involved in the decrease of enzyme solubility through alteration of the enzyme 'catalytic site'. Furthermore, Rasul et al. (2006) stated that these microorganisms would likely have low substrate use efficiency. Thus, by directing organic substrate utilization for the maintenance of metabolic activity, micro-organisms could overcome temporary salinity stress (Tate, 1995; Li et al. 2006).

\section{CONCLUSIONS}

In conclusion, both MSW compost and Sewage sludge affected soil physical and chemical properties and biological activities. The positive effect of the organic amendments on soil biological quality is due to the stimulation of microbial growth and/or to the addition of microbial cells or enzymes with the amendment, which can counteract the negative effect of salinity. This hypothesis seems to be reliably supported by the increase observed for more than one soil enzyme activity that very likely behaved as valid indicators of soil biological activity. However, a balance between adequate fertilization and the possible environmental risks caused by over fertilization must be considered.

\section{REFERENCES}

Eivazi, F., Tabatabai, M. A. 1990. Factors affecting glucosidase and galactosidase activities in soils. Soil Biol. Biochem. 22, 891-897.

El-Shakweer, M. H. A., El-Sayad, E. A., Ewees, M. S. A. 1998. Soil and plant analysis as a guide for interpretation of the improvement efficiency of organic conditioners added to different soil in Egypt. Comm. Soil Sci. Plant Anal. 29, 2067-2088.

Garcia, C., Hernandez, T., Costa, F., Ceccanti, B. 1994. Biochemical parameters in soils regenerated by the addition of organic wastes. Waste Manag. Res. 12, 457-466.

Garcia, C., Hernandez, T., Pascual, J.A., Moreno, J. L., Ros, M. 2000. Microbial activity in soils of SE Spain exposed to degradation and desertification processes. Strategies for their rehabilitation. In: C. Garcia, M.T. Hernandez (eds.), Research and Perspectives of Soil Enzymology in Spain. CEBAS-CSIC, Spain, pp: 93-143.

Hanay, A., Biiyiiksonmez, F., Kiziloglu, F. M., Canbolat, M. Y. 2004. Reclamation of Saline-Sodic Soils with Gypsum and MSW Compost. Compost Sci. Utiliz. 2, 175-179.

Hargreaves, J.C., Adl, M.S., Warman, P.R., 2008. A review of the use of composted municipal solid waste in agriculture. Agr. Ecosyst. Environ. 123, 1-14.

Kandeler, E., Gerber, H., 1988. Short-term assay of soil urease activity using colorimetric determination of ammonium. Biol. Fertil. Soils $6,68-72$.

Lakhdar, A., Hafsi, C., Rabhi, M., Debez, A., Montemurro, F., Abdelly, C., Jedidi, N., Ouerghi, Z. 2008. Application of municipal solid waste compost reduces the negative effects of saline water in Hordeum maritimum L. Biores. Technol. 99, 7160-7167. 
Li, X., Li, F., Bhupinderpal, S., Cui, Z., Rengel, Z. 2006. Decomposition of maize straw in saline soil. Biol. Fertil. Soils 42, 366370 .

Liang, Y., Nikolic, M., Peng, Y., Chen, W., Jiang, Y. 2005. Organic manure stimulates biological activity and barley growth in soil subject to secondary salinization. Soil Biol. Biochem. 37, 1185-1195.

Liang, Y., Yang, Y., Yang, C., Shen, Q., Zhou, J., Yang, L. 2003. Soil enzymatic activity and growth of rice and barley as influenced by organic manure in an anthropogenic soil. Geoderma 115, 149-160.

Madejon, E., Burgos, P., Lopez, R., Cabrera, F. 2001. Soil enzymatic response to addition of heavy metals with organic residues. Biol. Fertil. Soils 34, 144-150.

Marschner, P., Kandeler, E., Marschner, B. 2003. Structure and function of the soil microbial community in a long-term fertilizer experiment. Soil Biol. Biochem. 35, 453-461.

Masciandaro, G., Ceccanti, B., Benedicto S., Lee, H. C., Cook, F. 2004. Enzyme activity and $\mathrm{C}$ and $\mathrm{N}$ pools in soil following application of mulches. Can. J. Soil Sci. 84:19-30.

Pathak, H., Rao, D. L. N. 1998. Carbon and nitrogen mineralization from added organic matter in saline and alkali soils. Soil Biol. Biochem. 30, 695-702.

Rao, D. L. N., Pathak, H. 1996. Ameliorative influence of organic matter on biological activity of salt-affected soils. Arid Soil Res. Rehabil. 10, 311-319.

Rasul, G., Appahn, A., Müller, T., Joergensen, R. G. 2006. Salinity induced changes in the microbial use of sugarcane filter cake added to soil. Appl. Soil Ecol. 31, $1-10$.
Rodriguez-Kabana, R., Truelove, B. 1982. Effects of crop rotation and fertilization on catalase activity in a soil of the south-eastern United States. Plant Soil 69, 97-104.

Sannino, F., Gianfreda, L. 2001. Pesticide influence on soil enzymatic activities. Chemosphere 22, 1-9.

Tabatabai, M.A., Bremner, J.M. 1970 Arylsulphatase activity of soils. Soil Sci. Soc. Am. Proc. 34, 427-9.

Tate, R.L. III 1995. Soil microbiology. Wiley, New York.

Tejada, M., Garcia, C., Gonzalez, J. L., Hernandez, M. T., 2006. Use of organic amendment as a strategy for saline soil remediation: influence on the physical, chemical and biological properties of soil. Soil Biol. Biochem. 38, 1413-1421.

Trevors, J.T. 1984. Dehydrogenase activity in soil. A comparison between the INT and TTC assay. Soil Biology \& Biochemistry 16, 673674.

Tsadilas, C., Samaras, V. 1998. Influence of sewage sludge application on soil quality: I. Organic matter, $\mathrm{pH}$, phosphorus, potassium, and inorganic nitrogen. Proceedings of the Fourth International Conference of Precision Agriculture, St. Paul, Minnesota, USA, 19-22 July 1998. Part A and Part B.

Walker, D. J., Bernal, M. P. 2008. The effects of olive mill waste compost and poultry manure on the availability and plant uptake of nutrients in a highly saline soil. Biores. Technol. 99, 396-403. 